\title{
Pole pracy Misjonarzy Oblatów Maryi Niepokalanej w Afryce w XIX wieku
}

\author{
The field of work of the Missionary Oblates of Mary Immaculate in Africa \\ in the $19^{\text {th }}$ century
}

Zdecydowana większość terenów pracy misyjnej oblatów w XIX w. w Afryce przypada na Afrykę Południową. „W niniejszym tekście nie wspominamy o północnoafrykańskim epizodzie misyjnym oblatów, o misji, którą św. Eugeniusz przyjął w Algierii i po kilkunastu miesiącach z niej zrezygnował".

Choć podstawowym odniesieniem w ewangelizacji są zawsze ludy, nie ziemie, to jednak ważnym jest przeanalizowanie, gdzie rzeczywiście omawiana działalność misyjna była prowadzona. Tekst ten może sprawiać wrażenie pracy bardzo geograficznej, więc wypełnienie omówionego tutaj terenu treścią ewangelizacyjna, pozostawiamy już kolejnemu opracowaniu.

Na terenie Afryki południowej wylądował już w 1487 r. B. Diaz, a w 1497 r. w obecnym Natalu, V. da Gama. Historia misji katolickich na tym terenie zaczyna się jednak dopiero w XIX w. Co prawda pierwszą Mszę św. sprawował tam kapłan płynący z portugalskimi żeglarzami już w 1487 r., a pierwszy kościół został wybudowany w 1501 r., jednak w 1510 r. zostali tam zabici wszyscy Europejczycy (portugalski wicekról Indii Francisco de Almeida wraz ze swymi 65 ludźmi). Przez ponad sto lat nie pojawił się tam żaden europejski osadnik czy kolonizator ${ }^{1}$.

Guida delle Missioni Cattoliche, Roma ${ }^{6}$ 1989, s. 151; J. Metzler, Die Missionen in Südafrica und auf den ostafrikanischen Inseln, w: J. Metzler (red.), Memoria Rerum Sacrae Congregationis de Propaganda Fide. 350 anni a servizio delle Missioni. 1622 - 1972, t. III / 1, s. 295-296; J. Balicki, Historia Burów. Geneza państwa apartheidu, Wrocław 1980, s. 11. 
W 1652 r. do Zatoki Stołowej dotarły okręty holenderskiej ${ }^{2}$ Zjednoczonej Kompanii Wschodnioindyjskiej (Verenigde Oost-Indische Compagnie) ${ }^{3}$. Od tego momentu rozpoczął się napływ osadników holenderskich. Holenderscy kalwini nie wpuszczali na swój teren misjonarzy katolickich. Dopiero, gdy na początku XIX w. kolonia przeszła definitywnie w ręce angielskie, a rząd ogłosił w $1804 \mathrm{r}$. wolność religijną ${ }^{4}$, katolicy mogli rozpocząć działalność misyjną .

W 1818 r. erygowany został wikariat apostolski Przylądka Dobrej Nadziei. Nie udało się jednak bpowi Slaterowi OSB osiedlić w Kapsztadzie. Jego siedzibą stała się wyspa Mauritius ${ }^{6}$. Rok później oba wikariaty (Przylądka i Mauritius) połączono w jeden?

W 1837 r. papież Grzegorz XVI rozdzielił oba terytoria i mianował wikariuszem apostolskim Przylądka Dobrej Nadziei bpa Griffitha OP. W 1847 r. wikariat Przylądka został podzielony na: wikariat apostolski Przylądka Dobrej Nadziei i Dystrykt Zachodni z bpem Griffithem w Kapsztadzie i wikariat apostolski Przylądka Dobrej Nadziei i Dystrykt Wschodni z bpem Devereux w Port Elizabeth. Za sprawą tego drugiego, w roku 1850, powstał wikariat apostolski Natalu, który został powierzony oblatom ${ }^{8}$.

\footnotetext{
${ }^{2}$ Ściślej rzec biorąc była to Republika Zjednoczonych Prowincji zwana skrótowo od nazwy największej prowincji Holandią.

${ }^{3}$ Republika Zjednoczonych Prowincji posiadała swoistą formę władania imperium kolonialnym. Władzy w koloniach nie sprawowały bezpośrednie organy Republiki, lecz dwie spółki akcyjne, wyposażone w atrybuty władzy państwowej. W marcu 1602 r. Stany Generalne powierzyły monopol handlowy na obszarze na wschód od Przylądka Dobrej Nadziei i na zachód od Cieśniny Magellana Zjednoczonej Kompanii Wschodnioindyjskiej (Verenigde Oost-Indische Compagnie w skrócie VOC). Status Kompanii nadawał jej przywilej wykonywania praw suwerennych i w imieniu Republiki na terytoriach, które mogła zdobyć, prawo posiadania armii i floty, wypowiadania wojny i zawierania pokoju. Stany Generalne w teorii sprawowały kontrolę nad działalnością VOC, w praktyce jednak władze Kompanii robiły, co chciały. Na ogół VOC nie kwapiła się do podbojów terytorialnych, ale mile widziała monopol handlowy.

Jeśli chodzi o działalność misyjną, to pod panowaniem VOC nigdy nie było wystarczającej liczby duchownych (kalwińskich). Przez cały czas jej trwania (ok. 200 lat - XVII i XVIII w.) przebywało ich łącznie nie więcej niż dwa tysiące. Duchowieństwo katolickie w koloniach hiszpańskich i portugalskich było wielokrotnie liczniejsze. Dla pełności obrazu trzeba wspomnieć, że istniała też Kompania Zachodnioindyjska (West-Indische Compagnie - WIC). Jej działalność nie ma jednak związku z niniejszą pracą. Więcej informacji o VOC i WIC znaleźć można: J. Balicki, M. Bogucka, Historia Holandii, Wrocław 1989, s. 225-255.

${ }^{4}$ Metzler, art. cyt., s. 296. J. B. Brain, Catholic beginning in Natal and beyond, Durban 1975, s. $1-8$.

${ }^{5} \mathrm{O}$ czasach kolonizacji holenderskiej zob. Balicki, dz. cyt., s. 26-54. O kolonizacji angielskiej zob. Tamże, s. 55-74.

${ }^{6}$ T. Dusza, Kościoły lokalne Afryki, Rzym 1980, s. 14.

${ }^{7}$ Metzler, art. cyt., s. 299.

${ }^{8}$ Metzler, art. cyt., s. 304-307; Dusza, dz. cyt., s. 16 i 397; A. Roche, ,Świat należy do tego, kto bardziej pokocha...”. Błog. O. Józef Gérard OMI - Apostot Basutosów, Poznań 1989, s. 54.
} 
Przed XIX w. katolicy nie mogli tu prowadzić działalności misyjnej, ale również protestancka działalność misyjna rozwinęła się tu dopiero w XIX w. Nie prowadził jej z powodów wyznaniowych Kalwiński Kościół Afrykański, w którego skład wchodziły: Nederduits-Gereformeerde Kerk, Nederduits-Hervormde Kerk i Gereformeerde Kerk ${ }^{9}$.

W tym samym czasie, w którym przybywali do południowej Afryki misjonarze katoliccy, miała miejsce swoista „inwazja” misjonarzy protestanckich. Już od 1737 r. pracowali tu Bracia Morawscy, w 1799 r. przysłało swych misjonarzy Londyńskie Towarzystwo Misyjne (London Missionary Society), w 1816 r. pojawili się wesleylanie, w 1829 r. pracę podjęło Reńskie Towarzystwo Misyjne (Rheinisch-Evangelische Missionsgesellschaft) i Paryskie Towarzystwo Misyjne (Société des Missions Évangéliques de Paris) ${ }^{10}$, w 1834 r. Berlińskie Towarzystwo Misyjne (Berliner Missionsgesellschaft), a w 1848 r. Kościół Anglikański1"

Jeśli wziąć po uwagę różnorodne grupy misjonarzy protestanckich, a także katolickich z różnych zgromadzeń, to okazuje się, że kościelne „rozchwytywanie" Afryki było bardzo skomplikowane. Po stronie katolickiej powstała wkrótce sieć wikariatów podporządkowanych rzymskiej Kongregacji Rozkrzewiania Wiary i podjęta została rozbudowa Kościoła na niebywałą skalę. Nigdy dotąd Kościół katolicki nie rzucił na front misyjny tak wielkiej liczby ludzi. Pod względem organizacji i metod okres ten, jeśli chodzi o działalność misyjną, przewyższył poprzednie ${ }^{12}$.

Dziewiętnasty wiek, zwłaszcza jego druga połowa, jest czasem wielu zmian, wojen i tworzenia się organizacji państwowych na tych terenach. Aby uniknąć omawiania na każdym miejscu historii politycznej, wydaje się koniecznym przedstawić ją wpierw w ogólnym zarysie (dla pierwszych czterech terytoriów).

Głębokie zmiany na Przylądku spowodowane były ekspansją Brytyjczyków. W 1833 r. zniesione zostało niewolnictwo, na którym w znacznej mierze opierał się dobrobyt Burów, osiedleńców pochodzenia holenderskiego. W 1835 r. rozpoczęła się ich wielka wędrówka na północ, tzw. Wielki Trek (Groot Trek). Udali się oni poza rzekę Orange i jej dopływ Vaal, wszędzie po drodze wypierając ludność rodzima. W 1838 r. utworzyli Republikę Natalu. Podporządkowanie Natalu w 1843 r. Wielkiej Brytanii spowodowało drugą falę Wielkiego Treku, w trakcie której Burowie opanowali terytorium zachodniego Transwalu oraz obszar między rzekami Orange, Vaal i Vet. Wkrótce jednak, w 1848 r., i te tereny zostały

${ }^{9}$ A. Grzybowski, Religia w procesie ksztatcenia się narodu afrykanerskiego, w: A. MrozekDumanowska (red.), Religie w procesie przemian w Afryce, Wrocław 1977, s. 144 i 149-162.

${ }^{10}$ Oblaci spotkali się z nimi bezpośrednio w Basutolandzie.

${ }^{11}$ A. Perbal, Les missions acceptées par Mgr de Mazenod de 1841 à 1861, „Etudes Oblates” 23 (1964) s. 127.

${ }^{12}$ A. Hastings, Kościót i misje w Afryce, Warszawa 1971, s. 81. 
zaanektowane przez Koronę. Wobec tego Burowie skierowali się na północ od Vaal, gdzie utworzyli Republikę Transwalu. Jej suwerenność uznali Brytyjczycy w 1852 r. Gdy w dwa lata później Wielka Brytania zrezygnowała z kontroli nad terenem zajętym w roku 1848, Burowie natychmiast ogłosili powstanie drugiej republiki - Wolnego Państwa Orange, również uznanego przez Koronę. Oprócz tych dwóch, istniały przejściowo jeszcze trzy inne mniejsze republiki.

W 1866 r. odkryto pokłady diamentów w Wolnym Państwie, a w 1884 r. w Transwalu. Spowodowało to przypływ wielu osadników i poszukiwaczy z różnych krajów Europy. Tereny rolnicze zaczęły się zmieniać w przemysłowe. Powstawały ośrodki kopalń, a od 1875 r. zaczęto zakładać linie kolejowe.

W 1877 r. Wielka Brytania ogłosiła aneksję Transwalu. W odpowiedzi na to Burowie wzniecili powstanie, zadając Anglikom kilka dotkliwych porażek. Układem w Pretorii (1881 r.) Anglicy znów uznali samodzielność Transwalu. W 1885 r. wzięła Korona pod swój protektorat kraj Beczuana. W toku drugiej wojny angielsko-burskiej, w latach 1899-1902, obie republiki burskie zostały podbite i formalnie anektowane przez Wielką Brytanię w 1902 r. $^{13}$.

Pole pracy misyjnej oblatów zostanie przedstawione według obszarów misyjnych, jakie istniały na tym terenie u schyłku XIX w. Zaprezentowane zostana: wikariat apostolski Natalu, prefektura apostolska Basutolandu, wikariat apostolski Wolnego Państwa Orange, prefektura apostolska Transwalu i prefektura apostolska Dolnej Cymbebazji.

\section{WIKARIAT APOSTOLSKI NATALU}

Pod tą nazwą rozumieć można dwa różne obszary - przed i po podziale z 1886 r. Niewiele uogólniając można powiedzieć, że teren wikariatu przed $1886 \mathrm{r}$. odpowiada terenowi wikariatów Natalu i Wolnego Państwa Orange oraz prefektur Basutolandu i Transwalu w 1900 r. W brewe erekcyjnym wikariatu Natalu (1850 r.) granice nie zostały jeszcze jednoznacznie określone, co jednak przy ówczesnej znajomości interioru południowoafrykańskiego nie może dziwić. Granice te miały zostać ustalone między zainteresowanymi ordynariuszami i przełożonymi misji. Wikariat obejmował Natal, „Kafrarię” czyli Transkei, Zululand, Basutolandu, Wolne Państwo Orange, Transwal oraz część Griqualandu i Swazilandu. Jako granica północna podawane było ad tropicum usque. Precyzyjniej

\footnotetext{
${ }^{13}$ Dokładniejsze wiadomości znaleźć można u: Balicki, dz. cyt., s. 104-157. O wojnie angielsko-burskiej 1899-1902 opowiada książka: F. Bernaś, Na wzgórzach Transwalu, Warszawa 1986, zwłaszcza strony 140-236. W języku polskim istnieje spora liczba pozycji monograficznych poświęconych Afryce południowej, ale w zasadzie tylko w jednym aspekcie - dyskryminacji rasowej. Jest jednak również $\mathrm{w}$ tych pozycjach przedstawiana skrótowo historia.
} 
granice określono dopiero w roku $1876^{14}$, a w roku 1880 zachodni Griqualand poddany został jurysdykcji biskupa z Przylądka ${ }^{15}$.

W 1886 r. wikariat został podzielony i w tej części interesować nas będzie tylko ten obszar po podziale. Wikariat rozciagał się wtedy na tereny Natalu, Transkei, Zululandu i Swazilandu.

15 marca 1852 r. wikariusz apostolski, bp Allard OMI, wraz z czterema pierwszymi misjonarzami dotarł do miasta Durban. W rozległym wikariacie nie było kościołów, a ludność katolicka była bardzo rozproszona i liczyła ok. 500 Europejczyków. Od listopada 1850 do maja 1851 r. przebywał w Pietermartzburgu ks. Murphy z wikariatu Port Elizabeth, a w Bloemfontein pracował o. J. Hoenderwangers OProem. W tym czasie nie było jednak żadnej misji wśród ludności rodzimej ${ }^{16}$.

Swą pracę rozpoczęli oblaci w 1852 r. od posługi wśród katolików Durbanu i Pietermaritzburga oraz w okolicy. Ta posługa oznaczała czasem długie wyprawy, 200-300 km, a nawet do $800 \mathrm{~km}$ od domu ${ }^{17}$. Misjonarz z Durbanu, o. Sabon, wziął w opiekę w 1860 r. grupę ok. 1600 osób pochodzenia hinduskiego, z której tylko 300 było katolikami ${ }^{18}$.

Pierwszą placówkę typowo misyjną założono w lutym 1855 r. p. w. św. Michała (ok. $100 \mathrm{~km}$ na południe od Pietermaritzburga). Gorliwość misjonarzy natrafiła jednak na zupełną obojętność ludności miejscowej. Gdy w roku następnym okoliczny szczep Zulusów został przepędzony przez nieprzyjaciół, w lipcu 1856 r. misję zamknięto. Po dwóch latach otwarto ją ponownie, ale tym razem już nie na ziemi przydzielonej przez miejscowego naczelnika, lecz danej przez rząd. Niestety, nie przynosiła ona pożądanych skutków, więc w 1863 r. zamknięto ją ponownie $^{19}$. W roku $1890 \mathrm{w}$ tej okolicy podjęli pracę trapiści z Mariannhill ${ }^{20}$.

${ }^{14}$ Metzler, art. cyt., s. 309-310; N. Kowalsky, L'érection du vicariat apostolique du Natal selon les documents des Archives de la Propagande, „Etudes Oblates” 10 (1951) s. 283-287; Nouvelles Diverses, „Missions OMI” 24 (1886) s. 278-279. Szerzej zob. F. Hagel, The Founding of the Natal Vicariate, „Etudes Oblates” 9 (1950) s. 44-65.

${ }^{15}$ D. Levasseur, Histoire des Missionnaires Oblats de Marie Immaculée. Essai de synthèse, t. II, 1898-1985, Montreal 1986, s. 233.

${ }^{16}$ Levasseur, dz. cyt., t. I - 1815 - 1898, Montreal 1983, s. 160.

${ }^{17}$ T. Ortolan, Cent ans d'Apostolat dans les deux Hémisphères. Les Oblats de Marie Immaculée durant le premier siecle de leur eristance, t. II, En dehors de l'Europe (Jusqu'a à la mort du vénéré Fondateur) 1841 - 1861, Paris 1915, s. 458.

${ }^{18}$ Levasseur, dz. cyt., t. I, s. 161.

${ }^{19}$ Levasseur, dz. cyt., I, s. 162-164; A. Roche, dz. cyt., s. 60-69 i 72. Ten ostatni sugeruje, jakby to nie była dawna stacja na nowo otworzona, lecz zupełnie nowa, jedynie mająca tego samego patrona.

${ }^{20}$ Przybyli oni do Mariannhill z przeorem Pfannerem w 1880 r. Dwa lata później założyli klasztor podniesiony w 1885 r. do rangi opactwa. W 1921 r. erygowany został tam wikariat apostolski, a w 1951 r. diecezja. Więcej informacji o nich zob. Metzler, art. cyt., s. 313-314; Brain, dz. cyt., s. 162-173. O powiązaniach z oblatami zob. F. Hagel, Mariannhill's Founder and the Oblates, 
Przy ciagłym naleganiu Założyciela, aby podjąć misje „wśród Kafrów”, podjęto drugą próbę w $1860 \mathrm{r}$. W dolinie Évete, $32 \mathrm{~km}$ od ujścia rzeki Umzimkulu, gdzie uciekł szczep przepędzony z pierwszej misji św. Michała otwarto misję pw. Matki Boskiej Siedmiu Boleści. Znów misjonarzy spotkał zawód i ostatecznie misję opuszczono w lipcu 1861 r., gdy szczep rozproszył się z powodu epidemii ${ }^{21}$.

Nową misję postanowiono założyć bardziej na zachód, na terenie Basutolandu. Będzie o tym mowa w trzeciej części rozdziału.

Bp Allard obdarzony pełnomocnictwami Stolicy Apostolskiej próbował nieść również pomoc grupie katolików w Delagoa Bay w Mozambiku, gdzie od $1834 \mathrm{r}$. nie było kapłana. O. Bompart spędził rok (1864-1865) w Lorenço Marquez, lecz musiał opuścić to miejsce, ponieważ władza cywilna wymagała, aby zrzekł się jurysdykcji bpa Allarda i podporządkował abpowi z Goa ${ }^{22}$.

Mimo że oblatów spotkało na tym terenie pasmo niepowodzeń, nie upadli na duchu i dalej nie szczędzili trudu głosząc Słowo Boże w innych częściach wikariatu, o których będzie mowa nieco później. Kiedy w 1874 r. bp Jolivet OMI został mianowany wikariuszem Natalu, wystapił z inicjatywą podziału tego olbrzymiego terenu na mniejsze okręgi. Stolica Apostolska przychyliła się do tej propozycji w roku 1886, dzieląc dotychczasowy wikariat na: wikariaty Natalu i Wolnego Państwa Orange oraz prefekturę Transwalu. W tym zmniejszonym wikariacie Natal pole pracy misyjnej można sprowadzić do trzech dystryktów.

\section{Dystrykt północny}

Jak już zostało wspomniane, oblaci pracowali w Pietermaritzburgu i okolicy od $1852 \mathrm{r}$. Jednak nowe rezydencje i stacje misyjne zaczęły tu powstawać dopiero w ciagu ostatnich dwudziestu lat XIX w.

W 1885 r., na północ od Pietermaritzburga, została założona rezydencja w Estcourt, w 1880 r. akcja w Greytown ${ }^{23}$, nieco dalej, w roku 1896, w Ladysmith $^{24}$ i jeszcze dalej na północ w Newcastle ${ }^{25}$.

„Etudes Oblates” 6 (1947) s. 210-212. W języku polskim wydawany był miesięcznik „Wiadomości misyjne. Pismo poświęcone OO. Misjonarzom z Mariannhill w Południowej Afryce”, Katowice 1890-1903, Wrocław 1904-1939. Żadna z polskich bibliotek nie posiada kompletu tego czasopisma. Najwięcej roczników można znaleźć w Niepokalanowie i w Bibliotece Uniwersyteckiej we Wrocławiu (za: T. Dusza, Czasopisma misyjne w polskich bibliotekach, Warszawa 1980, s. 146).

${ }^{21}$ Levasseur, dz. cyt., I, s. 163-164; Roche, dz. cyt., s. 69-72.

${ }^{22} \mathrm{O}$ wyprawie do Lorenço zob. Lettres du Mgr Allard et des Pères Barret, Bompart et Sabon, „Missions OMI” 5 (1866) s. 25-52 i 6 (1867) s. 94-107.

${ }^{23}$ Personnel O.M.I. 1987, Roma 1987 (dalej jako: Personel 1987), s. 316. Nie znają jej personele z lat 1895-1904, więc prawdopodobnie rezydencją stała się dopiero w XX w.

${ }^{24}$ État général du Personnel de la Congrégation des Missionaires Oblats de Marie Immaculée. (No 5) - Avril 1899, b. m. r. (dalej jako: Personel 1899), s. 100.

${ }^{25}$ État général du Personnel de la Congrégation des Missionaires Oblats de Marie Immacu- 
Rezydencje te służyły jako punkt oparcia w pracy zarówno wśród ludności pochodzenia miejscowego, jak i europejskiego.

\section{Dystrykt południowo-wschodni}

Centrum tego okręgu, podobnie jak i poprzedniego, był dom założony jeszcze w roku 1852, w Durbanie.

Najstarszą rezydencja, typowo misyjną tego dystryktu był punkt Bluff założony w 1880 r., leżący nie opodal Durbanu ${ }^{26}$.

Wkrótce między Durbanem a Pietermaritzburgiem, w 1884 r., została założona rezydencja Oakford z filiami Victoria, Blackburn i Verulam ${ }^{27}$.

Również sam dom w Durbanie posiadał od roku 1888 filię w Clairmont ${ }^{28}$.

Ponadto ok. $100 \mathrm{~km}$ na północ, blisko oceanu, w 1895 r. założono rezydencję w Emoyeni, a nieco później, w latach 1899-1904 ok. 100 km na południe od Durbanu, również nad brzegiem oceanu powstały rezydencje: Umzinto, Port Shepstone, Umsisini (Mount Kerry) ${ }^{29}$. O podróżach misyjnych w tej okolicy (Zululand) dużo wiadomości podaje o. Rousset ${ }^{30}$.

\section{Transkei (Kafraria)}

Jest to terytorium leżące na południe od kolonii Natal. „Kraj leżący między rzekami Umzimkulu i Kei, łańcuchem Gór Smoczych i Oceanem Indyjskim”31.

Stolicą Transkei była wtedy Umtata ${ }^{32}$. Do rezydującego tam garnizonu przy-

lée. No 4 - Janvier 1895, Paris 1895 (dalej jako: Personel 1895), s. 90 (wtedy aktualnie bez rezydenta). Rapport du vicariat de Natal, „Missions OMI” 36 (1898) s. 393-398. W 1898 r. miała nawet swoją filię Dundee. Nie wspominają o niej następne personele. Być może zniszczona w czasie wojny.

${ }^{26}$ Szerzej o powstaniu tej placówki zob. A. Baudry, Lettre, „Missions OMI” 20 (1882) s. 158-177. Rezydencją stała się między rokiem 1895 a 1899 (Personel 1899, s. 99). Do założenia tej placówki bardzo przyczynił się świecki człowiek, Saturnino do Valle. O nim i założeniu tej placówki zob. H. S. George, A Lay Apostle of the Nineteenth Century. Saturnino do Valle, Pionier of Zulu Catholicizm, „Etudes Oblates” 25 (1966) s. 135-152.

${ }^{27}$ Rapport sur le vicariat de Natal, ,Missions OMI” 31 (1893) s. 486; Rapport du vicariat de Natal, „Missions OMI” 36 (1898) s. 393-398. Między 1899 a 1904 r. Verulam stało się rezydencją (État général du Personnel de la Congrégation des Missionnaires Oblats de Marie Immaculée. No 6 - Décembre 1904, Bar-Le-Duc b. r. - dalej jako: Personel 1904, s. 81).

${ }^{28}$ Rapport sur le vicariat de Natal, „Missions OMI” 31 (1893) s. 484.

${ }^{29}$ Personel 1904, s. 82.

${ }^{30}$ A. Rousset, Excursions à travers le Zoulouland, „Missions OMI” 44 (1906) s. 82-104.

${ }^{31}$ A. Schoch, Lettre - Mission de la Cafrerie, ,Missions OMI” 28 (1890) s. 74 (tłum. własne).

${ }^{32}$ W 1930 r. erygowano prefekturę apostolską Umtata, w 1937 r. wikariat apostolski, a w 1951 r. diecezję (Annuario Pontificio per l'anno 1990, Città del Vaticano 1990, s. 694). 
jeżdżał w latach 1880-1881 ks. Fagan z wikariatu Grahamstown. Pierwszy oblat, o. Baudry, pojawił się tam w tym samym czasie, lecz stałą rezydencję założono dopiero w 1883 r. rezydujący tu misjonarz obejmował swą opieką nie tylko miasto, ale odwiedzał również liczne punkty misyjne. $Z$ większych można wymienić: St-John, Keka, Tsolo, Qumlu, Xalanga, Indwe i Kentano ${ }^{33}$.

Drugim ważnym ośrodkiem był Koksztad ${ }^{34}$, gdzie w 1884 r. założono rezydencję, z której odwiedzano punkty: Fort Donald, Mount-Ayliff, Cedaraville (dziś Cedara), Matatiel, Mount-Fletcher a nawet dalekie Chin-Chase ${ }^{35}$.

Między tymi dwoma ośrodkami leżała stacja w Mount-Frere, którą obsługiwali misjonarze z powyższych domów. Przez pewien czas były one nawet samodzielną rezydencją ${ }^{36}$.

Podobnie Cala - początkowo filia Umtata, w 1893 r. stała się rezydencją ${ }^{37}$.

Ponadto Scharsch wspomina o jakiejś misji Bunting w Pondolandzie (część Transkei $)^{38}$. Być może jest to ta sama, o której wspomina o. Schoch nie podając nazwy ${ }^{39}$.

Przy omawianiu Transkei trzeba dodać, że na tym terenie bardzo rozwinęli swą działalność misjonarze z Mariannhill, którzy z czasem (ale już w XX w.) przejęli wszystkie oblackie placówki.

\section{PREFEKTURA APOSTOLSKA BASUTOLANDU}

Mały Basutoland (dzisiejsze Lesotho) otoczony przez kolonie i republiki Afryki południowej, zamieszkały był przez ludność miejscową, która pod wpływem wodza Moshoeshoe uformowała się w latach dwudziestych i trzydziestych XIX w. w jeden naród. W chwili przybycia oblatów kraj ten nie miał jeszcze definitywnych granic, ponieważ musiał o nie walczyć z Burami. W 1868 r. poddał się pod brytyjski protektorat.

Do 1886 r. teren ten należał do wikariatu Natalu, a następnie przez 8 lat do wikariatu Wolnego Państwa Orange. W roku 1894 został od niego odłączony jako

${ }^{33}$ A. Schoch, Lettre - Mission de la Cafrerie, „Missions OMI” 28 (1890) s. 74-79.

${ }^{34}$ Region w okolicy Koksztadu nazywany bywa Wschodnim Griqualandem w odróżnieniu od Zachodniego Griqualandu (okolice Kimberley) - zob. A. Schoch, Lettre, „Missions OMI” 29 (1891) s. 168.

${ }^{35}$ Tamże, s. 172.

${ }^{36}$ Personel 1895, s. 91.

${ }^{37}$ Obszerną historię tej misji zob. C. Le Bras, Lettre, „Missions OMI” 38 (1900) s. 212-222.

${ }^{38}$ P. Scharsch, Geschichte der Kongregation der Oblaten der Heiligsten und Unbeflecten Jugfrau Maria von ihrem Anfange bis zum Tode des dritten Generalobern. 1816 - 1897, t. II, Unter den Generalobern P. Joseph Fabre und P. Louis Soullier. 1861-1897, St Karl 1953, s. 621.

${ }^{39}$ A. Schoch, Lettre - Mission de la Cafrerie, ,Missions OMI” 28 (1890) s. 81. 
niezależna prefektura apostolska ${ }^{40}$. Na jej czele stali: o. Monginoux (prefekt w latach 1894-1895), o. Baudry (administrator apostolski w latach 1895-1897) i o. Cénez (prefekt od 1897 r.). Wszyscy oni byli oblatami ${ }^{41}$.

Protestanccy misjonarze (z Société des Missionnaires Évangéliques de Paris) rozpoczęli na tym terenie dzieło misyjne już w $1833 \mathrm{r}^{42}$. Po początkowych niepowodzeniach w Natalu, oblaci przybyli tu w 1862 r. Osiedlili się w dolinie Tlo-u-tle nazywając swą misję „Wioską Matki Jezusowej” (Motsi ha „M”a Jesu). Uroczyście została ona otwarta 1 listopada $1863 \mathrm{r}^{43}$. Z czasem jednak, z powodu katolickości, wierności Rzymowi przyjęła się nazwa Roma. W kraju tym nie było właściwie ludności pochodzenia europejskiego. Pole pracy oblatów zostanie omówione z północy na południe.

\section{Dystrykt św. Moniki}

Najbardziej wysuniętą na północ była rezydencja św. Moniki (dziś Leribe) ${ }^{44}$, która założona została w $1873 \mathrm{r}^{45}$. Z czasem powstała jej filia, stacja bł. Małgorzaty Marii, zastapiona później przez stację św. Anny ${ }^{46}$. W 1886 r. założono jeszcze jedną, nową rezydencję p. w. N.-D. de Sion (w dzisiejszym Mapoteng) ${ }^{47}$.

Stacje te stanowiły bazę i punkt wyjściowy dla oblatów pracujących na północy kraju. Misjonarze łatwo obchodzili całą okolicę, ponieważ miejscowa ludność mieszkała w małych wioskach położonych blisko siebie. Nie było więc potrzeby tworzenia dodatkowych stacji misyjnych, tak jak to było np. w Kanadzie.

\section{Dystrykt Roma}

Trochę na południe od Sion leżała rezydencja Getsemani. Z powodu wojen jej założenie przeciągało się od roku 1879 do $1882^{48}$.

${ }^{40} \mathrm{Wg}$ Guida, dz. cyt., s. 97 było to w roku 1839 (błędnie przestawione dwie ostatnie cyfry). Powszechnie jednak przyjmuje się rok 1894. Tak podaje np. Annuario, dz. cyt., s. 397, a nawet sama Guida przy omawianiu archidiecezji Maseru (s. 933).

${ }^{41}$ Levasseur, dz. cyt., I, s. 266.

${ }^{42}$ Ich działalność do 1862 r. (przybycie oblatów) omawia W. J. Vogt, Christianity in Basutoland 1833-1862. An Account of Christian missionary activity in Basutoland before the arrival of the first Catholic Missionaires, „Etudes Oblates” 21 (1962) s. 341-364.

${ }^{43}$ J. Gérard, Lettre au Père J. Fabre, Supérieur Général à Paris. Village de la Mère de Jésus, le 7 XII 1863,w: Le bienheureux Joseph Gérard OMI l'apôtre des Basotho (1831-1914). Lettres aux Supérieurs Généraux et autres Oblats. Écrits spirituels, Rome 1988, s. 34.

${ }^{44}$ Diec. Leribe erygowana w 1951 r. (Annuario, dz. cyt., s. 350).

${ }^{45}$ Personel 1895, s. 96.

${ }^{46}$ Rapport sur le vicariat de l'État Libre d'Orange, „Missions OMI” 31 (1893) s. 502; Basutoland. Rapport présenté au Chapitre Général de 1904, „Missions OMI” 43 (1905) s. 447.

${ }^{47}$ Personel 1899, s. 105.

${ }^{48}$ Scharsch, dz. cyt., t. II, s. 608-609. 
O założeniu „misji - matki” w Roma już wspomniano. Posiadała ona kilka pomocniczych stacji misyjnych. Do największych należały: św. Michała (zał. w 1868 r.), Nazaret (przy Thako - zał. 1883), Betlejem (na Thaba Bosiu - zał. $1894)^{49}$, Lorette (rzadko Loretto, przy Maseru), Betania (w Matsieng).

Niedaleko, na południe od Romy, leżała rezydencja św. Józefa w Koroko$\mathrm{ro}^{50}$, która również posiadała swoje filie: Masabielle ${ }^{51}$ i Pontmain ${ }^{52}$.

\section{Dystrykt Montolivet}

Praca misyjna oblatów na południu skupiała się wokół rezydencji Montolivet (w dzisiejszym Thabana Morena) założonej w $1882 \mathrm{r} .{ }^{53}$ i posiadającej filię św. Gabriela w Guthing. Filia ta była chrześcijańską enklawą w górach, dokąd po raz pierwszy dotarł w 1882 r. o. Le Bihan. Nie udało się tam jednak założyć w XIX w. stałej rezydencji ${ }^{54}$.

\section{WIKARIAT APOSTOLSKI WOLNEGO PAŃSTWA ORANGE}

Gdy w marcu 1852 r. do Natalu przybyli oblaci, republika Wolnego Państwa Orange miała jedną misję, w Bloemfontein ${ }^{55}$. W styczniu tegoż roku osiedlił się tam o. Hoenderwangers OProem. Pierwsza wyprawa oblatów na te tereny miała miejsce dopiero w latach 1861-1862 (bp Allard i o. Gérard). Oblaci jednak nie osiedlili się tam na stałe tak długo, dopóki działał tam o. Hoenderwangers ${ }^{56}$. Opuścił on Bloemfontein w 1869 r.

Wikariat powstał w 1886 r. w wyniku podziału wikariatu Natalu. Początkowo obejmował Wolne Państwo Orange, Basutoland oraz obszar pól diamentowych w Zachodnim Griqualandzie (do rzeki Vaal). W 1890 r. dołączono pozo-

\footnotetext{
${ }^{49}$ Pierwsza stacja misyjna w tym miejscu zniszczona podczas wojny. Druga założona w $1898 \mathrm{r}$. (Scharsch, dz. cyt., t. II, s. 815).

${ }^{50} \mathrm{Wg}$ Personel 1899, s. 105 założona w 1866 r., ale Personel 1895 takiej rezydencji nie zna. Wg Personel 1987, s. 338 założona w 1888 r. Prawdopodobnie wcześniej stacją, a później rezydencją.

${ }^{51}$ J. Rommerskirchen, Obrazki misyjne z kraju Basutosów, Poznań 1932, s. 121 podaje, że było to w Tsin.

${ }^{52}$ Mówi o niej dopiero J. Pennerath, Lettre, „Missions OMI” 40 (1902) s. 180. Jest to list z 29 stycznia 1902 r. Mówi o filii jako nowej.

${ }_{53}$ Personel 1895, s. 96.

${ }^{54} \mathrm{O}$ wizycie o. Le Bihana wspomina E. Derriennic, Lettre-rapport sur la Mission de St-Gabriel, Quthing, „Missions OMI” 44 (1906) s. 61. Raporty wikariatu z 1893 i 1899 r. w ogóle o niej nie wspominają. W 1904 r. była już rezydencją (Personel 1904, s. 84).

${ }^{55}$ W 1951 r. została utworzona archidiec. Bloemfontein (Annuario, dz. cyt., s. 95).

${ }^{56}$ Scharsch, dz. cyt., t. II, s. 573.
} 
stałą większą część Zachodniego Griqualandu (odłączona od wikariatu Cymbebazji). Dalsze rozszerzenie na zachód nastapiło w 1892 r. przez przyłączenie Beczuanalandu. W 1894 r. odłączono od wikariatu tereny Basutolandu, które stały się odrębną prefekturą ${ }^{57}$. Na czele wikariatu przez cały interesujący nas czas stał bp Gaughren OMI.

Teren tego wikariatu dla przejrzystości omawianego zagadnienia również został podzielony na trzy dystrykty.

\section{Dystrykt Bloemfontein}

Pierwsi misjonarze pracowali tu głównie wśród katolików rozproszonych po miastach i fermach burskich. W 1869 r. o. Le Bihan objął parafię w samym Bloemfontein $^{58}$, która od 1898 r. posiadała swe filie Brandfort i Kroomstad ${ }^{59}$.

Dla ułatwienia posługi misyjnej na tym terenie, otwarto jeszcze dwie inne rezydencje: w Jagersfontein (1881) i w Harrismith (1893) ${ }^{60}$. Posługa nie ograniczała się jednak tylko do tych miejscowości, bowiem misjonarze docierali w różne, nawet dość odległe zakątki kraju, jak np. Heilbron, Fickburg czy Karbe ${ }^{61}$.

W 1892 r. otwarte zostało przez oblatów kolegium w Clocolan, które jednak po trzech latach przekazano w inne ręce ${ }^{62}$.

\section{Dystrykt Kimberley (Zachodni Griqualand)}

Drugim polem działania w wikariacie była praca wśród europejskich imigrantów, którzy tłumnie przyjeżdżali na ziemie diamentów. W 1867 r. znaleziono pierwszy wielki diament, a w roku 1873 było już na tych terenach 40 tys. poszukiwaczy ${ }^{63}$.

Pierwsze wizyty rozpoczęto w $1870 \mathrm{r}$. W roku następnym otwarto rezydencję w Bultfontein, przeniesioną później do Kimberley (ówczesne New Rush) ${ }^{64}$.

\footnotetext{
${ }^{57}$ Nouvelles Diverses, „Missions OMI” 24 (1886) s. 278-279; Scharsch, dz. cyt., t. II, s. 632$-633$.

${ }^{58}$ Dom założono w 1870 r. (Personel 1899, s. 102).

${ }^{59}$ Rapport du vicariat de l'État Libre d'Orange, ,Missions OMI” 36 (1898) s. 401.

${ }^{60}$ Personel 1895, s. 93-94. Personel 1899, s. 102.

${ }^{61}$ Scharsch, dz. cyt., t. II, s. 573. F. Guiller, Rapport a Mgr Gaughren, vicaire apostolique, „Missions OMI” 26 (1888) s. 5-13.

${ }^{62}$ Levasseur, dz. cyt., t. I, s. 273.

${ }^{63}$ Scharsch, dz. cyt., t. II, s. 574.

${ }^{64}$ Personel 1895, s. 92 . Od 1886 r. Kimberley było siedzibą wikariusza apostolskiego, od 1951 r. jest stolicą diecezji (Annuario, dz. cyt., s. 316).
} 
$\mathrm{Z}$ tej rezydencji odwiedzano poszukiwaczy rozproszonych po kopalniach wzdłuż rzeki Vaal ${ }^{65}$.

Szybko okazało się, że sama rezydencja w Kimberley nie wystarcza, więc w roku 1879 otwarto drugą w pobliskim Beaconsfield ${ }^{66}$.

\section{Dystrykt Bechuanaland (dziś Botswana)}

Teren ten był już od lat trzydziestych ewangelizowany przez misjonarzy protestanckich. Z bardziej znanych misjonarzy wypada wspomnieć R. Moffata, który pracował od 1812 r. i D. Livingstone'a pracującego tu od 1840 r. w Kuruman. Najwięcej swych placówek miało tam: Londyńskie Towarzystwo Misyjne, Berlińskie Towarzystwo Misyjne oraz wesleylanie i anglikanie ${ }^{67}$.

Przed oblatami, przez niecałe 4 lata, próbowali tam pracować Misjonarze Ducha Św. Po przyłączeniu tego terenu do wikariatu Wolnego Państwa Orange (1892 r.) przejęli ten trudny teren oblaci. Do końca XIX w. zdołano założyć tam dwie misje: w Taung oraz w Mafeking (czasem pisane Mafikeng). Nie powiodła się jednak próba założenia misji w Gaberones. Misja Taung (zał. 1895 r.) była placówką służącą pracy misyjnej wśród ludności rodzimej, natomiast w Mafeking (zał. również w 1895 r.) praca koncentrowała się głównie wokół katolików pochodzenia europejskiego ${ }^{68}$.

\section{PREFEKTURA APOSTOLSKA TRANSWALU ${ }^{69}$}

Pierwszymi misjonarzami na tym terenie byli prawdopodobnie jezuici z Mozambiku, którzy pracowali tam w XVII w. Nie zachowały się jednak żadne

${ }^{65}$ Rapport sur le vicariat de l'État Libre d'Orange, ,Missions OMI” 31 (1893) s. 497 ; Rapport du vicariat de l'État Libre d'Orange, „Missions OMI” 36 (1898) s. 403. W latach 1871-1875 działał tam o. Le Bihan (Rommerskirchen, dz. cyt., s. 77.). O sytuacji na misjach w czasie wojny 1899-1902 zob. J. M. Morin, Lettre, „Missions OMI” 38 (1900) s. 199-212.

${ }^{66}$ Levasseur, dz. cyt., t. I, s. 272-273.

${ }^{67}$ Zob. Scharsch, dz. cyt., t. II, s. 804-807. F. Porte, Rapport à Mgr Gaughren, vicaire apostolique de l'État Libre d'Orange, „Missions OMI” 32 (1894) s. 194-221.

${ }^{68}$ Zob. Scharsch, dz. cyt., t. II, s. 804. Rapport du vicariat de l'État Libre d'Orange, ,Missions OMI" 36 (1898) s. 404-405; Vicariat Apostolique de Kimberley. Rapport présenté au Chapitre Général de 1904, „Missions OMI” 43 (1905) s. 438-439.

${ }^{69}$ Często w dokumentach oblackich spotyka się nazwę ,wikariat Transwalu”. Mowa tam jest jednak nie o wikariacie apostolskim, lecz o wikariacie misyjnym - jednostce administracyjnej Zgromadzenia, które dzieliło się wówczas na prowincje i wikariaty. Na ogół ich granice pokrywały się z granicami diecezji, wikariatów czy prefektur apostolskich, w których oblaci pracowali. W pracy niniejszej stosuje się tylko jednostki terytorialne ogólnokościelne, stąd mowa tu jest o prefekturze, a nie wikariacie Transwalu. Wikariat apostolski Transwalu erygowany został w 1904 r. (Metzler, art. cyt., s. 311). 
ślady ich działalności. Od czasu do czasu na te tereny docierał o. Hoenderwangers, a w 1869 i 1870 r. o. Le Bihan. Obaj odwiedzali jednak tylko katolików ówczesnej stolicy - Potchefstroom ${ }^{70}$, ponieważ dopiero w roku 1870 zniesiony został w tym kraju prawny zakaz innych kultów poza holendersko-reformowanym $^{71}$. W 1874 r. o. Walsh z Natalu udał się do Pilgrims Rest i do Lydenburga.

Aneksja Transwalu przez Brytyjczyków w 1877 r. oraz napływ emigrantów z Europy złagodziła trochę opozycję wobec przebywających w tym kraju kapłanów katolickich. Niestety, choć od 1870 r. kult katolicki był prawnie dopuszczany, to jednak misjonarze wciąż natrafiali na wrogość a przynajmniej niechęć. Poza tym pracy misyjnej bardzo zaszkodziła wojna trwająca w latach 1899$-1902^{72}$.

Pierwszy dom definitywnie otwarto w 1877 r. w Pretorii ${ }^{73}$. Był on tu jedyną placówką, gdy w $1886 \mathrm{r}$. erygowano prefekturę Transwalu. Na czele prefektury stał do 1891 r. o. Monginoux. Zmienił go w tymże roku o. Schoch, który zmarł w 1898 r.

W 1887 r. założono dom w leżącym nieco na południe Johannesburgu ${ }^{74}$. Tu, podobnie jak $\mathrm{z}$ domu $\mathrm{w}$ Pretorii, oblaci zajmowali się posługą misjonarską w okolicy, a w przylegającym do miasta Fordsburgu, późniejszej dzielnicy, otwarto dom, który stał się centrum całej pracy misyjnej w okolicy.

W okolicy Johannesburga znajdowała się jeszcze misja w Krugersdorp ${ }^{75}$, odwiedzana także przez misjonarzy z Fordsburga. Oblaci obsługiwali też parafie: Germiston (zał. w 1896 r.), Mayfair (zał. w 1892 r.), Pietersburg, Braamfontein i inne ${ }^{76}$ (dwie ostatnie przed 1904 r. przekazano duchowieństwu diecezjalne$\left.\mathrm{mu}^{77}\right)$.

${ }^{70}$ Rapport du O. Monginoux, préfet apostolique, „Missions OMI” 28 (1890) s. 172-173.

${ }^{71}$ Scharsch, dz. cyt., t. II, s. 578.

${ }^{72} \mathrm{~Np}$. od sierpnia do października 1899 r. opuściło Johannesburg ponad 120 tys. osób. Do tego trzeba dodać straty materialne misji. Zob. A. Baudry, Lettre, „Missions OMI” 37 (1899) zwłaszcza strona 479.

${ }^{73}$ Diecezja Pretoria erygowana w 1951 r., trzy lata wcześniej wikariat (Annuario, dz. cyt., s. 522).

${ }^{74}$ Personele z lat 1895-1899 nie podają dat założenia żadnego z domów, ani rezydencji. Personel z 1904 r. w ogóle nie podaje jakie domy i rezydencje oblaci posiadają w Transwalu. Od 1886 r. Johannesburg był siedzibą prefekta apostolskiego, od 1904 wikariusza, a od 1948 r. istnieje diec. Johannesburg (Annuario, dz. cyt., s. 294).

${ }^{75}$ Nie było to jeszcze rezydencja, ta powstała dopiero w roku 1956 (Personel 1987, s. 330).

${ }^{76}$ Podobnie rezydencja Germiston powstała dopiero w 1956 r. (Personel 1987, s. 326). Mayfair rezydencją od 1955 r. (Tamże). W 1910 r. erygowana została prefektura Północnego Transwalu z siedzibą w Pietersburgu, a od 1988 r. istnieje diec. Pietersburg (Annuario, dz. cyt., s. 503).

${ }^{77}$ Vicariat du Transvaal. Rapport présenté au Chapitre Général de 1904, „Missions OMI” 43 (1905) s. 456. 
Na południowy zachód od powyższych domów, w 1889 r., założono rezydencję $\mathrm{w}$ Potchefstroom ${ }^{78}$. Misjonarze docierali tu już na początku lat siedemdziesiątych, a nawet w 1869 r. Rezydencja Potchefstroom była punktem wyjścia działalności wśród katolików rozproszonych po okolicznych fermach burskich. Niedaleko Potchefstroom leżała stacja w Klerksdorp (zał. 1896 r.) ${ }^{79}$, odwiedzana przez misjonarzy z tego miasta.

W północno-wschodniej części Transwalu, od 1892 r., znajdowała się rezydencja w Lydenburgu ${ }^{80}$. Jednak o. Walsh przebywał tam już od 1878 r. zajmując się duszpasterstwem w miejscowym garnizonie ${ }^{81}$. Ponieważ zbyt daleko było do Pretorii, w 1886 r. otwarto rezydencję w leżącym nie opodal Barberton ${ }^{82}$. Była to głównie baza dla misjonarzy pracujących wśród górników, posiadająca swe filie w: Moodies, Steynsdorp, Eureka City, Jamestown i (do roku 1892) Lydenburg ${ }^{83}$. Misjonarze z Lydenburga odwiedzali też m.in. Elandowalley oraz pracowali wśród budowniczych kolei biegnącej aż z Zatoki Delagoa ${ }^{84}$.

W północno-zachodniej części kraju w 1894 r. oblaci przejęli od jezuitów misję-fermę w Vleeschfontein. Była to placówka pomocnicza służąca pracy wśród ludności rodzimeje ${ }^{85}$.

\section{PREFEKTURA APOSTOLSKA DOLNEJ CYMBEBAZJI (DAMARALAND)}

W 1879 r. Stolica Apostolska utworzyła prefekturę Cymbebazji i powierzyła ją Misjonarzom Ducha Świętego (CSSp). W rok później zostali oni jednak stamtąd wypędzeni przez władze cywilne ${ }^{86}$. W roku 1884 Bismarck proklamował niemiecki protektorat nad tymi ziemiami nazywanymi odtąd Niemiecką Afryką Południowo-Zachodnią ${ }^{87}$. Z północnej części prefektury Cymbebazji w $1892 \mathrm{r}$. powstała prefektura Dolnej Cymbebazji, którą z kolei powierzono niemieckim

${ }^{78}$ Personel 1987, s. 366 mówi o założeniu stacji w 1889 r. (nie rezydencji). Rezydencję Potchefstroom znają jednak Personel 1895 (s. 98) i Personel 1899 (s. 107), choć nie podają daty jej założenia.

${ }^{79}$ Personel 1987, s. 365. Rezydencja założona dopiero w 1956 r.

${ }^{80}$ Atlas OMI 1990, Roma 1990, s. 132.

${ }^{81}$ W czasie wojny 1880-1881 musiał odejść razem z żołnierzami. Zob. Scharsch, dz. cyt., t. II, s. 603-605.

${ }^{82}$ Atlas OMI, dz. cyt., s. 132.

${ }^{83}$ Rapport du O. Monginoux, préfet apostolique, „Missions OMI” 28 (1890) s. 188. Rezydencji w Barberton nie wspomina już Personel 1899.

${ }^{84}$ Rapport sur la préfecture de Transvaal, „Missions OMI” 31 (1893) s. 512.

${ }^{85}$ Zob. Nouvelles Diverses, ,Missions OMI” 32 (1894) s. 516-517.

${ }^{86}$ Metzler, art. cyt., s. 318-321.

${ }^{87}$ W. Czapliński, A. Glados, W. Korta, Historia Niemiec, Wrocław 1990, s. 564. J. Pajewski, Historia powszechna 1871-1918, Warszawa 1971, s. 210; Scharsch, dz. cyt., t. II, s. 825. 
oblatom $^{88}$. Postąpiono tak m.in. dlatego, aby umożliwić oblatom osiedlenie się w Niemczech.

W czasie Kulturkampfu do Cesarstwa wejść mogły bowiem tylko te zakony, które pracowały na misjach w koloniach niemieckich, dlatego też pierwsi niemieccy oblaci nie mogli się osiedlić w Niemczech. Działalność misjonarzy katolickich nie była jednak mile widziana. Ustawa rządu berlińskiego zakazywała zakładania misji katolickich wśród ludności rodzimej tam, gdzie już istniały misje protestanckie. Dopiero w 1900 r. misje katolickie uzyskały pełne prawo działalności ${ }^{89}$.

$\mathrm{Na}$ interesującym nas terenie pracowali już od 1842 r. protestanccy misjonarze z Reńskiego Towarzystwa Misyjnego oraz misji Fińskich (Finnischen Mission) od 1870 r. Oznaczało to praktycznie, że pracę misyjną prowadzić będzie można jedynie nad rzeką Okawango na granicy północnej ${ }^{90}$.

W latach 1894-1895 kraj ten zwiedził o. Schoch (z Transwalu), aby sprawdzić, czy tereny te nadają się na misje. Zmarł on jednak w drodze morskiej do Rzymu $^{91}$. Pierwsi misjonarze przybyli tu w końcu 1896 r. osiedlili się w rezydencji Windhoek ${ }^{92}$. Swój apostolat musieli z początku ograniczyć do katolickich żołnierzy i kolonistów z okolicy. W 1899 r. założono rezydencję i sierociniec dla miejscowych dzieci w Klein Windhoek oraz rezydencję w Swakopmund i Aminuis $^{93}$. Trudno więc mówić o wielkim polu pracy w tak krótkim czasie i przy tak niesprzyjających okolicznościach.

Jeśli chodzi o pracę typowo misyjną, to o. Herrmann podejmował uciążliwe wyprawy, aby dotrzeć na upragniony teren nad Okawango. W interesującym nas czasie odbyły się trzy takie wyprawy w 1897, 1899 i 1900 r. Niestety choroby niszczyły zaprzęgi i żadna z nich nie dotarła na miejsce ${ }^{94}$. Właściwa praca w tej prefekturze rozwinęła się dopiero w początkach XX w., ale ten okres już nie wchodzi w zakres niniejszej pracy.

Celem tego artykułu było przeanalizowanie na jakich terenach w Afryce dziewiętnastowiecznej Misjonarze Oblaci Maryi Niepokalanej prowadzili działalność misyjną. Mam nadzieję, że po tym „rozeznaniu terenu” ktoś kolejny pokusi się o dokładniejszą analizę ich działalności w poszczególnych miejscach, a może nawet na całym kontynencie, jak ona konkretnie wyglądała.

\footnotetext{
${ }^{88}$ Metzler, art. cyt., s. 318-321.

${ }^{89}$ A. Nachtwey, La Mission du Sud-Ouest Africain allemand. Rapport du Préfet Apostolique, „Missions OMI” 46 (1908) s. 76-93.

${ }^{90}$ Tamże.

${ }^{91}$ J. Gotthart, Okawango. Wyprawy misyjne w Afryce poludniowej, Poznań 1931, s. 17.

${ }_{92}$ Personel 1899, s. 108. Atlas OMI, dz. cyt., s. 136. Wikariat Windhoek powstał w 1926 r. (Annuario, dz. cyt., s. 1008).

${ }^{93}$ Atlas OMI, dz. cyt., s. 136.

${ }^{94}$ J. Filiung, Essai de fondation d'une Mission parmi les Ovambo, „Missions OMI” 48 (1910) s. $462-465$.
} 


\section{SUMMARY}

In 1850 the Holy See entrusted missionary work in South Africa to a young at that time congregation of the Missionary Oblates of Mary Immaculate. Oblates undertook that work and after some time divided their work in the $19^{\text {th }}$ century into five different regions. At first they began their work in Natal, after that in Basutoland (now Lesotho), in the Free Orange State, in Transvaal, and at the end of the century also in Cymbebasie (today Namibia). As the first Oblate mission in Africa, this activity remains a point of reference to the further development of the conception of the Oblate missions in Africa.

\section{Key words:}

Missionary Oblates of Mary Immaculate, South Africa, Natal, Lesotho, Free Orange State, Transvaal, Namibia

\section{Słowa klucze:}

Misjonarze Oblaci Maryi Niepokalanej, Południowa Afryka, Natal, Lesotho, Wolne Państwo Orange, Transwal, Namibia 